\title{
IDENTIFYING LOW CARBON TECHNOLOGY FOR SUSTAINABLE ENERGY DEVELOPMENT IN INDONESIA
}

\author{
Identifikasi Teknologi Rendah Karbon Untuk Pengembangan \\ Energi Berkelanjutan di Indonesia
}

\author{
Kardono \\ Environmental Technology Center \\ Agency for the Assessment and Application of Technology \\ Geostech Bulding 820, PUSPIPTEK Area, Serpong, Tangerang Selatan, Indonesia, \\ E-mail: kardono@bppt.go.id
}

Diterima: 05 September 2013; Dikoreksi: 25 September 2013; Disetujui: 06 Oktober 2013

\begin{abstract}
Abstrak
Sebagai negara berkembang , Indonesia secara sukarela berkomitmen untuk mengurangi emisi gas rumah kaca (GRK) sebesar $26 \%$ dengan menggunakan biaya sendiri atau dengan menambahkan bantuan luar negeri sebesar $41 \%$ pada tahun 2020. Target ini akan membawa dampak bagi Indonesia untuk membuat rencana kerja dan pada waktu yang sama untuk memilih teknologi karbon rendah (LCT) dalam mengurangi gas rumah kaca tersebut. Makalah ini akan fokus memperkenalkan LCTs untuk sektor energi di Indonesia. Pemilihan Teknologi rendah karbon (LCTs) untuk mengurangi emisi CO2 di Indonesia dianjurkan untuk sisi penyediaan dan permintaan energi. Teknologi untuk penyediaan energi diprioritaskan untuk batubara, geotermal, dan teknologi energi terbarukan meliputi teknologi untuk biomasa, air, angin dan matahari. Teknologi untuk permintaan energi diterapkan untuk efisiensi energi di sektor industri, perumahan dan bangunan komersial. Selain itu, soft technology seperti audit energi, energy rating dan pelabelan juga diusulkan. Untuk transportasi dan taxi, bahan bakar gas sebagai pengganti bahan bakar fosil atau gasolin sangat disarankan untuk digunakan. Manajemen permintaan transportasi juga diusulkan untuk ditingkatkan, seperti menggunakan intelligent transportation system (ITS) dan mass rapid transport system (MRTS).
\end{abstract}

Kata kunci : Gas rumah kaca, teknologi rendah karbon, penyediaan dan permintaan energi.

\begin{abstract}
As a developing country, Indonesia has voluntarily committed to reduce its green-house gases (GHGs) emissions by $26 \%$ with its self-financing, or $41 \%$ with addition of foreign aids, by year 2020 . This target will carry consequences for Indonesia to make an action plan and at the same time to choose which low carbon technologies (LCTs) are employed in reducing its GHGs. This paper will focus on introducing LCTs for energy sector of Indonesia. LCTs option for reducing $\mathrm{CO}_{2}$ emission in Indonesia is suggested for both energy supply and energy demand sides. Energy technology for supply side is prioritized for clean coal, geothermal and renewable energy technologies including technologies for biomass, hydro, wind and solar. Prioritized energy technology for demand side is applied to energy efficiency for industries, residential and commercial buildings. Besides, soft technologies such as energy audit, energy rating and labeling are also proposed. For public bus transportation and taxi, a cleaner fuel of gas as a substitution to fossil fuel or gasoline is highly suggested to be used. Transport demand management is also proposed to be improved, like using intelligent transportation system (ITS) and mass rapid transport system (MRTS).
\end{abstract}

Keywords: greenhouse gases, low carbon technology, supply and demand side of energy.

\section{INTRODUCTION}

Indonesia, the world's largest archipelagic state and the world's fourth most populous country with more than $80 \%$ of its populations who live in agriculture and fishery sectors is highly susceptible to climate variability. High growth of economy in the last decades has led the growing demand of energy supply and utilization in the country. This growing energy demand goes in hand with increasing release of carbon $\left(\mathrm{CO}_{2}\right)$ emission $[1,2]$. 
Anthropogenic $\mathrm{CO}_{2}$ is the main source of $\mathrm{GHG}$ accumulating in the atmosphere[2]. This source in particular has been due to the use of fossil fuel. In many cases, the use of technology such as fossil fuel combustion causes negative impact on the environment, in addition to the benefit given by it to the people. Carbon dioxide emission from fossil combustion technology that causes global warming is an example of its negative impact to the environment. Actually, both developed and developing countries at certain levels have employed technologies that contribute the increase of the $\mathrm{CO}_{2}$ emission in the atmosphere [3].

Low carbon technology comes from processes or technologies that, at the point of generation release less carbon dioxide than the traditional means of power generation[4]. It includes zero carbon power generation sources, such as wind, solar, geothermal, nuclear power, as well as sources with slightly lower-level emissions than coal and oil, such as natural gas. Increase energy efficiency is also considered a low carbon technology since it generates less $\mathrm{CO}_{2}$ emission $[2,4]$.

\section{ENERGY GENERATION AND USE}

Total final energy consumption of Indonesia in 2006 was about 853.8 million BOE[5]. Its composition by sector was industry $(37.14 \%)$, residential $(36.65 \%)$, transportation $(20.09 \%)$, commercial $(2.57 \%)$, and others $(3.55 \%)$; as shown in Figure 1.

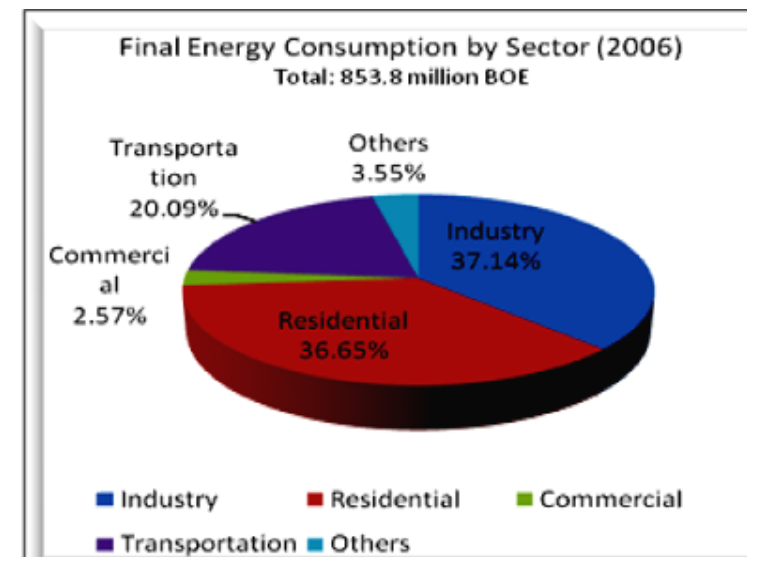

Figure 1. Final energy consumption by Sector 2006 (Source: Handbook of Energy \& Economic Statistics of Indonesia (2006) taken from TNA, 2009).

Composition of Indonesia electricity production based on fuel types is shown in Table 1[6]. The total electricity production in 2012 was 202,387 GWh and in 2020 it is predicted to increase to $371,374 \mathrm{GWh}$. Its composition in 2012 by fuel is HSD $(8.57 \%)$, MFO $(2.38 \%)$, gas $(21.09 \%)$, LNG $(3.74 \%)$, coal $(54.37 \%)$, hydro $(5.5 .4 \%)$, solar/ hybrid $(0.002 \%)$, biomass $(0.03 \%)$ and geothermal $(4.27 \%)$.

The predicted fuel composition for electricity generation in 2020 will be HSD (0.7\%), MFO $(0.02 \%)$, gas $(8.31 \%)$, LNG $(8.49 \%)$, coal $(64.2 \%)$, hydro $(5.77 \%)$, solar/hybrid $(0.002 \%)$, biomass $(0.02 \%)$, geothermal $(12.39 \%)$, and import $(0.09 \%)$ [6].Figure 2 shows the resulted $\mathrm{CO}_{2}$ emission if Indonesian electricity production is done with fuel mix as shown in Table 1. Figure 2 indicates that Indonesia $\mathrm{CO}_{2}$ emission will increase from 141 Million Tons in 2011 to 276 Million Tons in 2020[6]. Of 276 Million Tons $\mathrm{CO}_{2}$ e emission, 245 Million Tons $(89 \%)$ is contributed from coal combustion. Average grid emission factor for Indonesia in 2011 was $0.763 \mathrm{~kg} \mathrm{CO} / \mathrm{kWh}$. It will slightly increase to $0.8 \mathrm{~kg} \mathrm{CO} / \mathrm{kWh}$ in 2013-2014 but it will go down back to $0.745 \mathrm{~kg} \mathrm{CO} / \mathrm{kWh}$ in 2020 due to operation of geothermal and hydro power [6].

In addition to energy generation and utilization, these low carbon technologies will also discuss energy use for transportation, industry and household. In the total final energy use in transportation, household and industry, the shares come from petroleum $(65.9 \%)$, natural gas $(12.7 \%)$, coal $(7.4 \%)$, electricity $(12.5 \%)$ and LPG $(1.6 \%)[5]$.

Indonesian transportation, particularly road transportation consumes the biggest primary energy. About $88 \%$ of total primary energy consumption for all modes of transportation in the country is used by road transportation. The passenger cars dominate the energy consumption (38\%), followed by trucks, buses, and motorcycles at $32 \%, 18 \%$, and $12 \%$; respectively [5]. Industrial sector produces GHG emissions from both its energy utilization and its production processes. The growth of industrial sector is parallel with the growth of national economy. Since the national economy of Indonesia increases the GHG emissions from the industry will consequently increase. The commercial final energy consumption is about $53 \%$ of the total national final energy consumption [5].

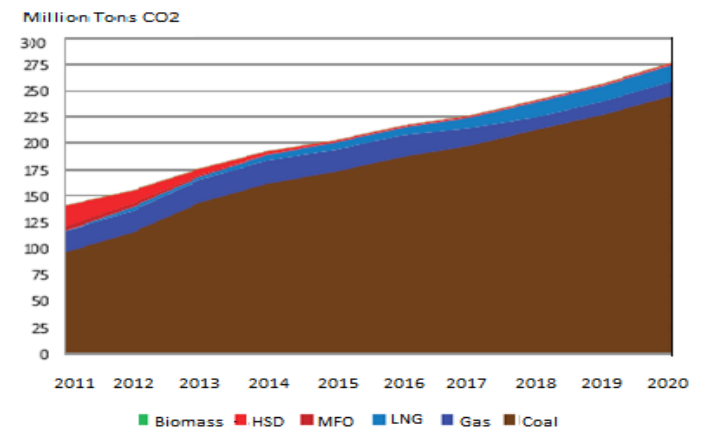

Figure 2. $\mathrm{CO}_{2}$ emission per fuel type (compounded Indonesia) (Source: RUPTL-PLN 2011-2020) 
Table 1. Composition of electricity production (GWh) based on total fuel types in 2012 and 2020. (Source: RUPTL-PLN 2011-2020)

\begin{tabular}{lllll}
\hline Fuel Type & 2012 & $\%$ & 2020 & $\%$ \\
\hline HSD & 17,346 & 8.57 & 2,635 & 0.71 \\
MFO & 4,807 & 2.38 & 65 & 0.02 \\
Gas & 42,691 & 21.09 & 30,879 & 8.31 \\
\hline LNG & 7,578 & 3.74 & 31,541 & 8.49 \\
Coal & 110,043 & 54.37 & 238,432 & 64.20 \\
Hydro & 11,204 & 5.54 & 21,429 & 5.77 \\
Solar/ Hybrid & 4 & 0.002 & 7 & 0.002 \\
Biomass & 63 & 0.03 & 63 & 0.02 \\
Import & & & 317 & 0.09 \\
Geothermal & 8,650 & 4.27 & 46,005 & 12.39 \\
Total & 202,386 & 100.00 & 371,373 & 100.00 \\
\hline
\end{tabular}

Tabel2.Emission reduction target of each sector in NAP-GHGs

(Source: Presidential RegulationNo. 61 of 2011)

\begin{tabular}{|l|l|l|l|}
\hline No & Sector & $\begin{array}{l}26 \% \text { Emission Reduction } \\
\text { (in Giga ton CO2e) }\end{array}$ & $\begin{array}{l}41 \% \text { Emission Reduction } \\
\text { (in Giga ton CO2e) }\end{array}$ \\
\hline 1 & Agriculture & 0.008 & 0.011 \\
\hline 2 & Forestry and peat-land & 0.672 & 1.039 \\
\hline 3 & Energy and Transportation & 0.038 & 0.056 \\
\hline 4 & Industry & 0.001 & 0.005 \\
\hline 5 & Waste management & 0.048 & 0.078 \\
\hline Total & 0.767 & 1.189 \\
\hline
\end{tabular}

Table 3. Electricity generation needed for Java-Bali (Source: RUPTL-PLN 2011-2020)

\begin{tabular}{|c|c|c|c|c|c|c|c|c|c|c|c|c|}
\hline No & Year & 2011 & 2012 & 2013 & 2014 & 2015 & \multicolumn{2}{|c|}{2016} & 2018 & 2019 & 2020 & Total \\
\hline 1 & Steam & $\begin{array}{l}3,88 \\
0\end{array}$ & 4,095 & 1,050 & 1,040 & 2,320 & \begin{tabular}{|l}
3 \\
5 \\
2 \\
0
\end{tabular} & 3,860 & 1,200 & 600 & 1,000 & $\begin{array}{l}22,56 \\
5\end{array}$ \\
\hline 2 & Geothermal & - & - & 60 & - & 385 & \begin{tabular}{|l|}
3 \\
2 \\
5 \\
\end{tabular} & 270 & 815 & 855 & 165 & 2,875 \\
\hline 3 & Gas-Steam & 594 & 743 & - & - & - & - & - & - & 750 & 750 & 2,837 \\
\hline 4 & Gas & & & & 150 & - & - & - & 400 & 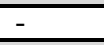 & 400 & 950 \\
\hline 5 & Minihydro & 9 & 4 & 68 & 18 & - & - & - & - & - & - & 99 \\
\hline 6 & Hydro & - & - & - & - & 257 & \begin{tabular}{|l|}
6 \\
2 \\
\end{tabular} & 37 & - & - & 18 & 374 \\
\hline 7 & Solar & - & - & - & - & - & \begin{tabular}{|l|}
1 \\
\\
0 \\
1 \\
0 \\
\end{tabular} & - & - & 450 & 950 & 2,440 \\
\hline 8 & Gas-Wind & - & & - & 3 & 3 & - & & & - & - & 6 \\
\hline & Total & $\begin{array}{l}4,48 \\
3\end{array}$ & 4,842 & 1,178 & 1,211 & 2,965 & \begin{tabular}{|l|}
4 \\
9 \\
\end{tabular} & 4,167 & 2,415 & 2,655 & 3,283 & $\begin{array}{l}32,11 \\
6\end{array}$ \\
\hline
\end{tabular}




\section{INDONESIAN GHG'S REDUCTION PLAN}

By 2020 , Indonesia has voluntarily declared to reduce its GHGs emissions by $26 \%$ with selffinancing or $41 \%$ with additional foreign aids [7]. This target has become a reference in designing and planning all technologies needed to reduce GHG emissions in each sector.

\section{IDENTIFYING LOW CARBON TECHNOLO- GIES FOR ENERGY SECTOR}

Beside a climate change reason on emission reduction targets, the low carbon technology can be as a determining factor in next economic era that leads to low carbon economy. There is currently however no clear or agreed definition of what constitutes a low carbon technology (LCT). Wikipedia[4] states that lowcarbon power comes from processes or technologies that, at the point of generation, release less carbon dioxide than the traditional means of power generation. In general term, low carbon power can be assumed as low carbon technology (LCT). It includes zero carbon power sources, such as wind power, solarpower, geothermal power and including fuel preparation and decommissioning, nuclear power, as well as sources with slightly lower-level emissions than coal, such as natural gas $[2,4]$.

For the case of Indonesia, clean coal technology is also considered to be low carbon technology. These powergeneration techniques emit significantly less carbon dioxide than a traditional fossil fuel power plant [7].

Low carbon technologies for targeted sectors in terms of reducing GHG emission in Indonesia have actually been established by the Government via President Regulation No. 61 year 2011[7].

\subsection{LCT for Energy Generation and Transportation}

For energy and transportation sector, targeted reduction of $\mathrm{GHG}$ emission by 2020 based on $26 \%$ $\mathrm{CO}_{2} \mathrm{e}$ reduction scenario is about $0.038 \mathrm{G}$.Ton $\mathrm{CO}_{2} \mathrm{e}$ and based on $41 \% \mathrm{CO}_{2} \mathrm{e}$ reduction scenario is about $0.056 \mathrm{G}$. Ton $\mathrm{CO}_{2} \mathrm{e}[7]$. They will be done through (1) increase of energy conservation, (2) clean fuel switching, (3) increase of new and renewable energy resources, (4) use of clean technology, and (5) sustainable low carbon development of national mass transportation.

The following action plans [7] for examples were formulated : (1) implementation of energy management for intensive energy users $(10,16 \mathrm{MT}$ $\left.\mathrm{CO}_{2} \mathrm{e}\right) ;(2)$ implementation of energy conservation partnership $\left(2,11 \quad \mathrm{MT} \quad \mathrm{CO}_{2} \mathrm{e}\right) ; \quad$ (3) increase household appliances' efficiency (9,82 $\left.\mathrm{MT} \mathrm{CO}_{2} \mathrm{e}\right)$; (4) accessibility and management of new and renewable energy and energy conservation such as development of micro-hydro, minihydro, solar, wind and biomass (4.4 MT CO2e); (5) biogas utilization (0.13 $\left.\mathrm{MT} \mathrm{CO}_{2} \mathrm{e}\right)$; (6) natural gas utilization for rural transportation (3.09 $\mathrm{MT} \mathrm{CO}_{2} \mathrm{e}$ ); (7) household gas transmission ( $0.15 \mathrm{MT} \mathrm{CO} 2 \mathrm{e})$; (8) development of intelligent transport system (1.77 MT $\mathrm{CO}_{2} \mathrm{e}$ ); parking management (1.07 MT $\left.\mathrm{CO}_{2} \mathrm{e}\right)$; (9) reformation of bus rapid transit (0.69 $\left.\mathrm{MT}^{2} \mathrm{CO}_{2} \mathrm{e}\right) ;(10)$ renewal of public transportation (0.36 MT $\left.\mathrm{CO}_{2} \mathrm{e}\right)$; and others.

In line with the government policy to utilize new and renewable energy resources as documented in the President Regulation Number 5 year 2006 regarding National Energy Policy[8], National Electric State Owned Company (PLN) has set up policy to prioritize geothermal and hydro power[6]. PLN has also received the task from the government to electrify rural communities that have not yet received electricity.

From this policy, PLN plans to develop geothermal with very big capacity, hydro power with large, medium and small capacity, and small scale of new and renewable energy like solar power, wind power, biomass, bio-fuel and coal gasification.

PLN also support research and development of other new and renewable energy sources such as thermal solar power, sea water current, ocean thermal energy conversion (OTEC) and fuel cell. Special for solar power system, PLN makes a policy to develop centralized PVs at large scale to electrify remote area communities a far from the grid and underdeveloped area, and front end islands next to neighboring countries[6].

Geothermal power is considered to be sustainable because the heat extraction is small compared to the Earth's heat content. The emission intensity of existing geothermal electric plants is about $122 \mathrm{~kg}$ of $\mathrm{CO}_{2}$ per megawatt-hour (MWh); a small fraction of that conventional fossil is fuel plants[2,4]. Geothermal technology is selected by Indonesia because the resources are abundant and its utilization is still low. It is planned to enhance geothermal development up to 2,875 MW in the next 10 yearsin Java - Bali system (see Table 2)[6]. Deployment of advanced geothermal technology such as binary cycle might be suitable for some areas of Indonesia[9].

Hydroelectric plants have the advantage of being long-lived as many existing plants have operated for more than 100 years. Hydropower is also an extremely flexible technology from the perspective of power grid operation. Large hydropower provides one of the lowest cost options in today's energy market, even compared to fossil fuels and there are no harmful emissions associated with plant operation.Hydroelectric power is currently the world's largest installed renewable source based electricity, supplying 
Tabel 4.Identified low carbon technology for supply side

(Source: TNA 2009 Study of Indonesia)

\begin{tabular}{|c|c|c|c|}
\hline $\begin{array}{l}\text { Identified } \\
\text { technology }\end{array}$ & $\begin{array}{l}\text { Present } \\
\text { situation }\end{array}$ & Technology input & Emission reduction potential \\
\hline \multirow{6}{*}{$\begin{array}{l}\text { Advanced } \\
\text { thermal power } \\
\text { technology/ } \\
\text { clean coal } \\
\text { technology }\end{array}$} & \multirow{6}{*}{$\begin{array}{l}\text { Pulverized } \\
\text { Coal Power } \\
\text { Plant; } \\
\text { Thermal } \\
\text { efficiency: } \\
33 \%, 1 \text { ton } \\
\text { CO2/MWh }\end{array}$} & $\begin{array}{l}\text { Subcritical Pulverized } \\
\text { Coal Power Plant, } 36 \% \\
\text { eff. }\end{array}$ & $\begin{array}{l}0.70 \text { ton } \mathrm{CO} 2 / \mathrm{MWh} \text { (w/o CO2 } \\
\text { capture) } \\
0.830 \text { ton } \mathrm{CO} 2 / \mathrm{MWh}(\mathrm{w} / \mathrm{CO} 2 \\
\text { capture) }\end{array}$ \\
\hline & & $\begin{array}{l}\text { Supercritical and Ultra } \\
\text { Supercritical Pulverized } \\
\text { Coal Power Plant, 40-46 } \\
\% \text { efficiency } \\
\end{array}$ & $\begin{array}{l}0.170 \text { ton } \mathrm{CO} 2 / \mathrm{MWh}(\mathrm{w} / \mathrm{o} \mathrm{CO} 2 \\
\text { capture) } \\
0,891 \text { ton } \mathrm{CO} 2 / \mathrm{MWh}(\mathrm{w} / \mathrm{CO} 2 \\
\text { capture) }\end{array}$ \\
\hline & & Cogeneration & 0.325 ton $\mathrm{CO} 2 / \mathrm{MWh}$ \\
\hline & & IGCC, $38-41 \%$ eff. & $\begin{array}{l}0.168 \text { ton } \mathrm{CO} 2 / \mathrm{MWh} \text { w/ Pre- } \\
\text { combustion } \\
0.898 \text { ton } \mathrm{CO} 2 / \mathrm{MWh}, \mathrm{w} / \mathrm{CO} 2 \\
\text { capture }\end{array}$ \\
\hline & & Coal upgrading & $\begin{array}{l}\text { Vary depending on quality of } \\
\text { coal; } \\
5 \% \text { emission reduction of } \\
\text { conventional PC }\end{array}$ \\
\hline & & Improve efficiency. & $\begin{array}{l}1 \% \text { increase of eff. will reduce } 2 \\
2.5 \% \mathrm{CO} 2 \text { emission }\end{array}$ \\
\hline \multirow[t]{2}{*}{ Fuel switching } & \multirow[b]{2}{*}{$\begin{array}{l}\text { Combine } \\
\text { Cycle Gas } \\
\text { Turbine to } \\
\text { Replace } \\
\text { HSD } \\
\text { Generator }\end{array}$} & Gas to replace HSD & N.A \\
\hline & & Coal to Gas (50\%) & 0.5 ton $\mathrm{CO} 2 / \mathrm{MWh}$ \\
\hline \multirow{11}{*}{$\begin{array}{l}\text { Utilization of } \\
\text { renewable } \\
\text { energy } \\
\text { technology }\end{array}$} & $\begin{array}{l}\text { More than } \\
95 \% \text { of } \\
\text { primary } \\
\text { energy uses } \\
\text { oil, coal and } \\
\text { gas. }\end{array}$ & $\begin{array}{l}\text { Biomass Power - Co- } \\
\text { firing }\end{array}$ & $\begin{array}{l}15-20 \% \text { of emission reduction } \\
\text { depends on the main fuel. }\end{array}$ \\
\hline & \multirow{10}{*}{$\begin{array}{l}\text { Government } \\
\text { set a target } \\
\text { to reduce oil } \\
\text { but increase } \\
\text { new and } \\
\text { renewable } \\
\text { energy up to } \\
15 \% \text { of total } \\
\text { primary } \\
\text { energy mix, }\end{array}$} & $\begin{array}{l}\text { Biomass power- } \\
\text { gasification }\end{array}$ & $\begin{array}{l}\text { Avoid CO2 emission from coal } \\
\text { combustion. }\end{array}$ \\
\hline & & $\begin{array}{l}\text { Geothermal - Flash } \\
\text { Steam }\end{array}$ & \multirow{3}{*}{$\begin{array}{l}0.9-1 \text { ton } \mathrm{CO} 2 / \mathrm{MWh} \text { (depend } \\
\text { on type of PP replaced) }\end{array}$} \\
\hline & & $\begin{array}{l}\text { Geothermal - Binary } \\
\text { Cycle }\end{array}$ & \\
\hline & & $\begin{array}{l}\text { Geothermal- Hot Dry } \\
\text { Rock }\end{array}$ & \\
\hline & & $\begin{array}{l}\text { Photovoltaic - Single } \\
\text { Crystal/Mono }\end{array}$ & idem \\
\hline & & Wind turbine & idem \\
\hline & & Micro and Mini Hydro & idem \\
\hline & & Advanced Hydro Power & idem \\
\hline & & $\begin{array}{l}\text { Nuclear Power: } \\
\text { PWR/BWR } \\
\text { 2ndGeneneration }\end{array}$ & $\begin{array}{l}0.85-0.9 \text { ton } \mathrm{CO} 2 / \mathrm{MWh} \\
\text { (depend on type of power plant } \\
\text { replaced) }\end{array}$ \\
\hline & & $\begin{array}{l}\text { Nuclear Power } \\
\text { PWR/BWR 3/3+ } \\
\text { generation }\end{array}$ & idem \\
\hline
\end{tabular}


about $17 \%$ of total electricity in $2005[4]$. China is the world's largest producer of hydroelectricity, followed by Canada [4].

Hydroelectric power is one of renewable energy technologies selected by Indonesia. Its water resources are abundant however its utilization is still very low due to a huge budget to use it, in addition to social and environmental constraints.

Indonesia will initiate the use of wind power combined with the gas power forabout $6 \mathrm{MW}$ of energy output in the next 10 years for Java-Bali system. Technology chosen is improved efficiency and reliability of low-speed wind turbine, light material for blade, control system and motor and other main parts[6].

Indonesia will also build solar power system of about 2,440 MW in the next 10 years in Java-Bali system.

As seenin Table 3 the total additional capacity of electricity for the next 10 years in Java-Bali system will be $32,1 \mathrm{MW}$ or around 3,1 GW per year[6]. Steam coal combustion will still dominate the generation $(22,5 \mathrm{GW}$ or $70 \%)$ while steam gas generation will be the second (2.8 MW or $8.8 \%)$, followed by renewable energy such as geothermal (2.9 GW or $8.9 \%)$ and hydro/ minihydro/solar power (2.9 GW or $9.1 \%$ ), and finally gas power (1 $\mathrm{GW}$ or $3 \%)$.

Biomass is another source of energy for Indonesia, namely agriculture waste, agriculture biomass, palm oil, other bio-fuels, and industrial waste. Several biomass conversion technologies such as direct combustion and co-firing technology can help utilization of the potential resources[5]. In the last 15 years, several biomass plant projects such as biomass power generation using rice husk or straw have been introduced but the result was poor due to the continuity of the feedstock. Therefore, in addition to the deployment of biomass conversion technology, there is a need to develop data base of biomass resources potential in Indonesia which can be updated regularly.

Study on low carbon technologies in energy generation in the purpose of technology transfer was conducted[5] and part of the result can be seen in the following Table4.

Low carbon technology to reduce $\mathrm{CO}_{2}$ emission from transportation includes adoption of advanced vehicle technologies with less or no $\mathrm{CO}_{2}$ emission. Improvement of transportation management system, including advanced transportation control and development of mass rapid transit system is another option. It is also suggested to reduce the GHG's by using alternative fuel technology (bio-fuel and gaseous based fuels) for the vehicles. Other less greenhouse gases emission technologies such as hybrid gasoline/diesel -electric powered and bi-fueled (CNG) vehicles are also suggested[5]. The application of low GHGs emission technologies should be encouraged by the government through strategic measures anactions and involving all stakeholders (incding private, public and society). Measures are needed by the government to undertake the "Zero Growth Vehicles" policy in major cities of Indonesia. The development of mass rapid transit system especially in the metropolitan cities in Indonesia should be prioritized by the Central Government and Regional Government, as it is potentially reducing the greenhouse gaseous emission.

Table 5 shows the vehicle low carbon technology based upon the rate of fuel saving and Table 6 shows the vehicle LCT based upon selected alternative fuel [5].

Table 5. Selected vehicle technology(Source: TNA 2009 Study of Indonesia)

\begin{tabular}{|l|l|c|}
\hline No & \multicolumn{1}{|c|}{ Technology } & $\begin{array}{c}\text { Potential } \\
\mathrm{CO}_{2} \\
\text { reduction to } \\
\mathrm{BAU}(\%)\end{array}$ \\
\hline 2. & Cellulosic ethanol & $\approx 90$ \\
\hline 3. & Biodiesel fuel & $\approx 70$ \\
\hline 4. & Ethanol & $\approx 60$ \\
\hline 5. & CNG & $\approx 30$ \\
\hline 6. & LNG & $\approx 20$ \\
\hline 7. & LPG & $\approx 20$ \\
\hline
\end{tabular}

Table 6.Selected alternative fuel technology. (Source: TNA 2009 Study of Indonesia)

For industrial sector targeted reduction of

\begin{tabular}{|l|l|c|}
\hline No & \multicolumn{1}{|c|}{ Technology } & $\begin{array}{c}\% \\
\text { Fuel } \\
\text { Saving }\end{array}$ \\
\hline & Gasoline direct injection & $3-4$ \\
\hline & $\begin{array}{l}\text { Six-speed automatic } \\
\text { transmission }\end{array}$ & $4-5$ \\
\hline & $\begin{array}{l}\text { Continuously variable } \\
\text { transmission }\end{array}$ & $\approx 7$ \\
\hline & No Torque converter & $3-4$ \\
\hline & $\begin{array}{l}\text { Hybrid vehicle w/o } \\
\text { Torque converter }\end{array}$ & $30-40$ \\
\hline
\end{tabular}

GHG emission by 2020 based on $26 \%$ reduction scenario is about $0.001 \mathrm{G}$ Ton $\mathrm{CO}_{2} \mathrm{e}$ and based on $41 \%$ reduction scenario is about $0.005 \mathrm{G}$. Ton $\mathrm{CO}_{2} \mathrm{e}[7]$. They will be done through optimization 
of energy utilization. The action plans have been formulated and those are (1) the implementation of technology and process modification (2.75 MT $\left.\mathrm{CO}_{2} \mathrm{e}\right) ;(2)$ energy audit and conservation (4.81
MT $\left.\mathrm{CO}_{2} \mathrm{e}\right)$; and (3) passing out ozone depleting substances (1.5 $\left.\mathrm{MT} \mathrm{CO}_{2} \mathrm{e}\right)$.

Table 7 shows more detailed information on energy efficiency for demand side suggested by TNA Study (2009) [5] (Source: TNA 2009 Study of Indonesia)

\begin{tabular}{|c|c|c|c|}
\hline No & Technology & Efficiency measure & Result \\
\hline 1 & $\begin{array}{l}\text { CFL (Compact } \\
\text { Fluorescent Lamp) }\end{array}$ & $\begin{array}{l}\text { Replacement of incandescent } \\
\text { bulb with CFL }\end{array}$ & $\begin{array}{l}\text { Reduction up to } 80 \% \text { of energy } \\
\text { use }\end{array}$ \\
\hline 2 & Solar water heater & Solar water heater for hot water. & Electricity reduction up to $50 \%$ \\
\hline 3 & Electronic Ballast & Magnetic w/ electronic ballast. & $20 \%$ reduction of energy use \\
\hline 4 & High Efficiency AC & $\begin{array}{l}\text { Replacement of standard AC } \\
\text { with high efficiency AC }\end{array}$ & $\begin{array}{l}\text { Reducing energy cons up to } 50 \\
\%\end{array}$ \\
\hline 5 & HC Refrigerant & CFC with $\mathrm{HC}$ refrigerant & Electricity saving up to $20 \%$ \\
\hline 6 & $\begin{array}{l}\text { BAS (Building } \\
\text { Automatic System) }\end{array}$ & $\begin{array}{l}\text { Application of BAS to monitor } \\
\text { lightning and energy use in } \\
\text { building }\end{array}$ & Electricity saving $10-20 \%$. \\
\hline 7 & High Efficiency Chiller & $\begin{array}{l}\text { Normal chiller with high efficiency } \\
\text { chiller }\end{array}$ & $\begin{array}{l}\text { COP normal chiller }=4,0 \\
\text { COP high efficiency chiller }= \\
5,0 \text { for Comm. } \& \text { industry }\end{array}$ \\
\hline 8 & $\begin{array}{l}\text { High Efficiency Electric } \\
\text { Motor }\end{array}$ & $\begin{array}{l}\text { Replacement of normal electric } \\
\text { motor with high efficiency electric } \\
\text { motor }\end{array}$ & $\begin{array}{l}\text { High efficiency can reduce } \\
\text { energy consumption up tp } 25 \% \\
\text { for Industry. }\end{array}$ \\
\hline
\end{tabular}

The reduction of $\mathrm{GHG}$ emission from the industries is carried out by improving the process and energy utilization according to cleaner production mechanisms. These activities range from changing or retrofitting the equipment and materials that are not efficient anymore to optimizing the use of the waste for energy.

Grand strategy of energy conservation and $\mathrm{CO}_{2}$ emission reduction in industrial sector, 20102020 has been proposed[10]. This grand strategy shows that the way to reduce $\mathrm{CO}_{2}$ emission from targeted industries in order to share about $2 \%$ of $41 \%$ National $\mathrm{CO}_{2}$ e reduction is as follows.

The phase 1 implementation is energy conservation and $\mathrm{CO}_{2}$ emission reduction in industrial sector in 2011. It was done an energy audit for 35 steel industries and 15 pulp and paper industries.

Following technology audit, some recommendations were made with the following categories [10]:

No Cost and Low Cost, such as improvement of monitoring system and energy management; recuperating maintenance, heat waste utilization, insulation and coverage of steam pipe leaks.

Medium Cost, such as recuperating installation, bank capacitor improvement, dust collector inverter installation, blow-down heat recovery installation, flash tank equipment addition.

High Cost, such as new incinerator addition, variable speed driver addition, and recuperating change with the more efficient one.

Realization of these recommendations, their implementation strongly depends on capability of the industry and therefore it needs stimulation from the government.

In cement industry, LCT is used for energy efficiency because high contribution on $\mathrm{CO}_{2}$ emission from cement industry is due to coal fuel and electricity. Calcination of calcium carbonate is also a source of $\mathrm{CO}_{2}$ emission. Therefore the area of LCT for cement industry is :[10]

Fuel consumption reduction is done through for example burner modification, alternative fuel, heat waste recovery, use of high efficiency motor, and compressed air system optimization. Alternative raw material utilization such as limestone with low $\mathrm{CaCO} 3$, fly ash, bottom ash, etc.

Increase of grinding efficiency; Maintenance of general measures such as preventive maintenance, efficient lighting, automatic process control system and energy management.

\section{CONCLUSIONS}

There is a policy for low carbon technology 
established by the government of Indonesia through President Regulation No. 61 Year 2011 regarding National Action Plan on GHG reduction. The policy and strategy as well as the activities and targets have been formulated. The related sectors have also implemented those related action plans.

To reduce greenhouse gases for energy and transportation sectors and industrial sector, low carbon technology scenario is dedicated to reduce the GHGemission via pre-fossil combustion to avoid much more use of fossil energy, such as efficient energy technologies (high efficiency light, efficient appliances, etc.); renewable energytechnologies (geothermal, hydro, solar, wind, etc.); and fossil pre-treatment (coal upgrading). The reduction of GHG emission is also be done during fossil fuel combustion process, such asby using efficient technologies of combustors (co-generators), low carbon electric generation (high efficiency and low emission, IGCC, etc.), and clean fuel technology (fuel switching). At last, a post fossil combustion to mitigate emitted GHG from existing sources is also important to be conducted, such as through carbon capture and storage technologies and utilization of $\mathrm{CO}_{2}$ for biofuel and other products.

\section{REFERENCES}

1. Ministry of Environment and UNIDO. (2009). Indonesia Second National Communication Under the United Nation Framework Convention on Climate Change (UNFCCC).

2. Quanchning, V. (2010). Renewable Energy and Climate Change, HedyJourdan (Translator), A John Weley and Sons, Ltd, Publication.

3. IPCC. (2010). Special Report on Renewable Energy Sources and Climate Change Mitigation, in Press.

4. http://en.wikipedia.org/wiki/Low-carbon power,Accessed on 16 August 2012.

5. Ministry of Environment, BPPT and GTZ. (2010). Indonesia's Technology Needs Assessment on Climate Change Mitigation of 2009.

6. Rencana Usaha PenyediaanTenagaListrik (RUPTL), PT. PLN (Persero) 2011-2020, DiterbitkanolehSekretariat PT. PLN.

7. President Regulation No. 5 Year 2006 regarding National Energy Policy.

8. President Regulation No. 16 Year 2011 concerning National Action Plan on Green House Gases Reduction.

9. Agency for the Assessment and Application of Technology, 2012. "Energy Outlook 2012".

10. Ministry of Industry. (2012). Program of Industrial Revitalization and the Important of Incentive for Industries in order to Implement Clean and Efficient Energy Technology, Center for Green Industry and Environmental Assessment, Agency for the Assessment of Industrial Climate and Quality, presented on the workshop in Bogor, July 2012. 